\title{
Geomorphic settings of mangrove ecosystem in South Andaman Island: A geospatial approach
}

\author{
E Yuvaraj $^{1, *}$, K Dharanirajan ${ }^{1}$, S Jayakumar $^{2}$ and Saravanan ${ }^{1}$ \\ ${ }^{1}$ Department of Disaster Management, Pondicherry University, Port Blair, Andamans 744 112, India. \\ ${ }^{2}$ Department of Botany, JNRM College, Port Blair, Andamans 744 101, India. \\ *Corresponding author.e-mail: yuvaerd22@gmail.com
}

\begin{abstract}
Mangroves are habitats in the coasts of tropics and subtropics, hence the geomorphology of the coast prevails in both the ocean and the land processes. To study the geomorphic setting of mangroves, it is necessary to explore both the topography of the land and the bathymetry of the sea. In this study, the geomorphic setting of mangroves in the South Andaman Island has been studied in detail using remote sensing and GIS technology. The ortho-rectified IRS satellite image was used to identify and to map the mangroves and the associated features using the visual interpretation technique. Using the GIS technique, topographic and bathymetric DEMs (Digital Elevation Models) were created to understand the geomorphology and its influence on the mangrove ecosystem. This DEM was interpreted with mangrove distribution and its associated features to create the DTM (Digital Terrain Model) of the mangrove ecosystem. Topography and bathymetry of the coast result in three dominant features like rivers, tides and waves, which play a role in shaping the geomorphic settings of mangroves, which are classified into five major types. In this study, it is identified that all the five categories of major geomorphic settings of the mangrove community exist in the south Andaman. In the field surveys, ground truth of topographic elevation, mangrove species, and associated coastal land cover features were identified and confirmed in these geomorphic settings. It is concluded that topography and bathymetry settings of the island play an indispensable role in this fragile mangrove ecosystem.
\end{abstract}

\section{Introduction}

Mangroves are salt tolerant trees and shrubs which dominate the intertidal coasts of tropics and subtropics (Tomlinson 1986). These are well adapted communities which are highly complex and dynamic, thriving saline habitats with their special characters such as salt excreting leaves, exposed breathing root systems, and production of viviparous propagules (Duke 1992). Their litter production leads to most productive ecosystems and becomes forage ground for organic food, which promotes vital spawning and acts as a nursery for enormous aquatic organisms such as fish, crabs, etc. (Mumby et al. 2004; Subramanian 2004; Manson et al. 2005). Mangroves also act as barriers and protect the coast from the coastal disasters and erosion and accelerate accretion (Othman 1994;Kathiresan and Rajendran 2005; Alongi 2008). In recent decades, these productive and protective mangrove ecosystems are in vulnerable conditions worldwide threatened by human activities and also by natural calamities like cyclone and tsunami (Farnsworth and Ellison 1997; Gilman et al. 2008). In Andaman and Nicobar Islands (ANI), during the tsunami that struck in December 2004, mangroves played a key protective role; however there was extensive damage and

Keywords. Mangrove; south Andaman; geomorphic setting; topography; bathymetry; remote sensing and GIS. 
significant loss of mangroves (Ramachandran et al. 2005).

\subsection{Geomorphic setting of mangroves}

The function of environmental factors in land and ocean processes characterizes and places some constraints on particular coastal settings (Thom et al. 1975; Thom 1984; Woodroffe et al. 1980). These constraints are various combinations of geophysical processes and geomorphologic landscapes that produce a variety of subsidies and stressors to the ecological processes of mangroves (Robert and Victor 2005). It is necessary to study the mangrove distribution and structural types in relation to the geomorphic process, which is used to determine the mangrove community response in changing environmental factors (Stoddart 1980). Geomorphologic setting plays an important role in delta formation, tidal fluctuation, wind protection and so on. Different environmental settings change the habitat of mangroves sediment accumulation, both organic (autochthonous) and inorganic (allochthonous or terrigenous) (Thom 1984). Mangroves grow better in sheltered bays shielded by the headlands or islands which protect them from wind action compared to the exposed bays where the wind action results in coastal water drift, tidal current fluctuation, etc. (Oliver 1982).

\subsection{Remote sensing and GIS techniques}

Remote sensing and GIS techniques are widely proven techniques essential for mapping, monitoring and managing these mangrove ecosystems (Kuenzer et al. 2011). Geospatial studies like mangrove distribution, diversity, and dynamics were explored the mangrove forest in the South Andaman Island (IIRS 2003; SAC 2011). The distribution varies from small tidal estuaries to long inlets and lagoons (SAC 2011), which depend on coastal configuration and variation in substrata status (Rajagopalan 1987). Selvam (2003) identified geomorphic settings of several mangrove forests in India using coarse resolution satellite images which are limited to ANI. According to his study, the geomorphic setting of ANI mangrove forest was carbonate platforms of low energy coast. It is important to study the geomorphic setting of this fragile mangrove ecosystem in islands using high resolution satellite image to understand the variations in the distribution pattern of mangrove geomorphic settings. This study attempted to identify and understand the geomorphic setting of various mangrove forests of the South Andaman Island using high resolution satellite images, remote sensing, and GIS techniques.

\subsection{Regional setting - study area}

The study area in the South Andaman Island is located between $92^{\circ} 48^{\prime} \mathrm{E}, 11^{\circ} 57^{\prime} \mathrm{N}$ and $92^{\circ} 30^{\prime} \mathrm{E}$, $11^{\circ} 27^{\prime} \mathrm{N}$ with the Bay of Bengal in the west and the Andaman Sea at the east. The topography of the island varies from hilly terrain to small tracts of coastal fallow lands. The geology of Andamans are considered to be flysch sediments of Paleogene age and ophiolites and metamorphics of Late Cretaceous-Early Paleogene occur in the main ridge (Sharma and Shrinivasan 2007). All the rocks belong to the Late Cretaceous to Tertiary, with the Oligocene Flysch covering the western part and the Paleocene to Eocene sediments of Mithakari covering the eastern part (Gokarn et al. 2006). The climate is tropical hot humid with temperature ranges from $18^{\circ}$ to $35^{\circ} \mathrm{C}$, abundant rainfall of up to eight months, and average ranging from 3000 to $3500 \mathrm{~mm}$ in a year resulting in formation of very luxuriant and rich vegetation in this island (Chakravarthy et al. 1987; Das and Dev 1989). Due to the tribal reserved forest and difficulties in conducting the field survey in remote areas, only 12 stations were selected for this study, which is shown in figure 1 .

\section{Materials and methodology}

The IRS R2 satellite image was purchased from NRSC, India. This LISS IV sensor image has a spatial resolution of $5.6 \mathrm{~m}$, SOI toposheet (1979), and a bathymetry chart (2003); scale ranges of 1:25,000 and 1:50,000 respectively, were used to study the topography and the bathymetry of the study area. GPS was used for ground survey for error rectification and species correlation with appropriate settings. Software packages such as ARCGIS 10 and ERDAS IMAGINE 11 were used for image processing, analysing, modelling, and mapping purposes.

Remote sensing and GIS techniques were used to understand the geomorphic setting (Selvam 2003) and its influences in mangrove forest distribution of the South Andaman Island. The base map was prepared from the toposheet. Similarly, rivers and contours were also digitized in ArcGIS 10 software to study the topography of the coast. The bathymetry sheet was geo-registered with the toposheet and isobaths were extracted. The DEM was generated using contours and isobaths for elevation analysis purpose of the mangrove and its surrounding environment. The raw satellite image was processed using ERDAS 11 software and it was geo-rectified with the toposheet. The unpredicted existence of terrestrial plants was observed in some mangrove forests on this island since the classification techniques failed to show clear 


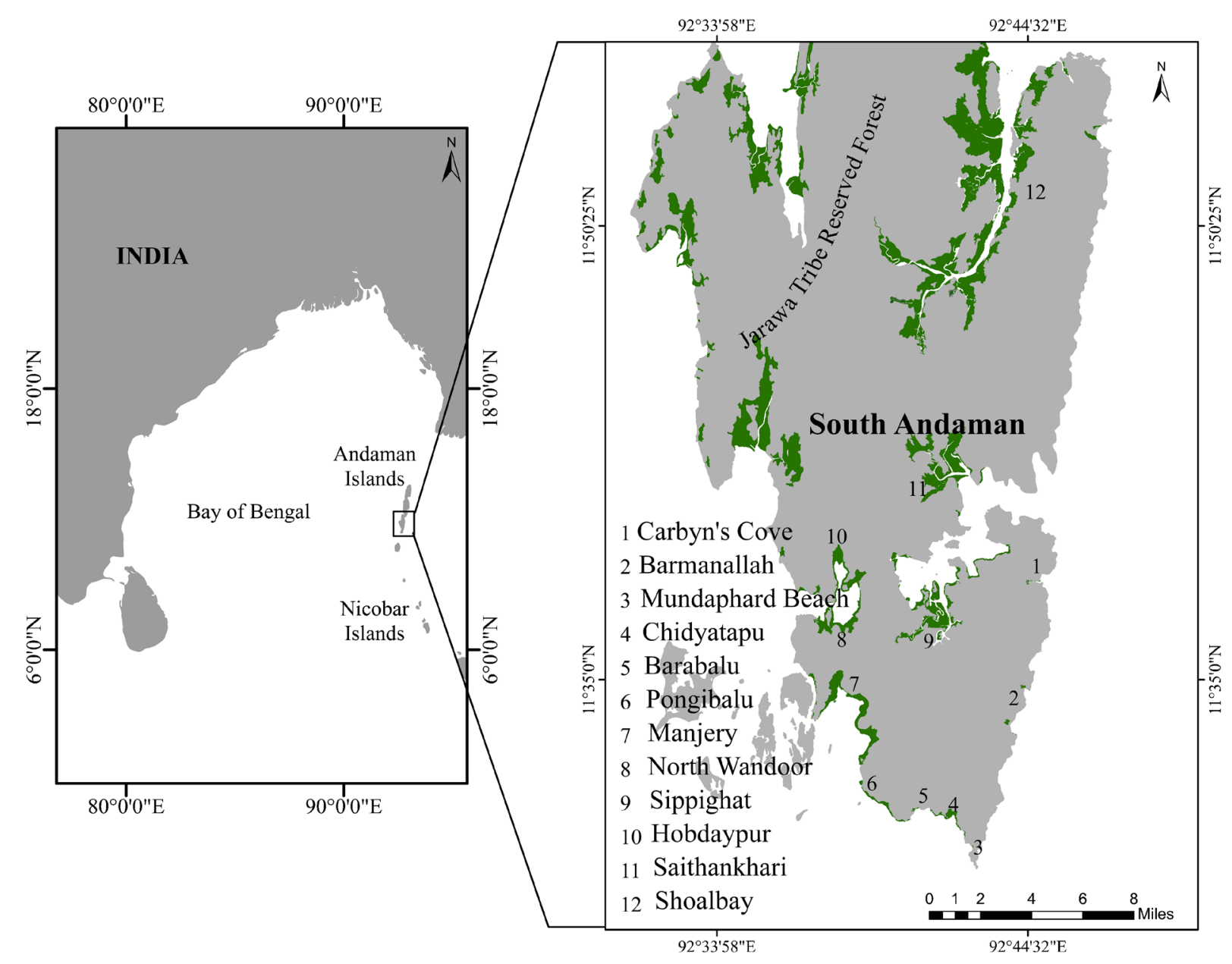

Figure 1. Map showing study areas in South Andaman Island.

distribution of mangroves. So visual interpretation techniques were used to identify the mangrove forest and associated features such as sandy beaches, lagoons, drowned bedrocks, and creeks in the False Colour Composite (FCC) of the satellite image using image interpretation key by SAC (1991). The FCC indicates the reverse arrangement of three bands such as green, red, and near-infrared of the LISS IV image; instead of true colour image, FCC provides wide information to delineate and map mangrove cover from other forests and also other land cover features (Gnanappazham and Selvam 2011). Dense and sparse forests and fine patches which are clearly identified in the satellite images were considered for this study. These coastal land cover features are added to the existing DEM to create the Digital Terrain Model (DTM) to analyze the mangrove environment. The DTM outputs of Arc-Scene platform were interpreted with classification of mangrove geomorphic settings by Thom (1984). He depicted five major geomorphic settings of the mangrove habitat which is the modified form of delta classification of Wright et al. (1974) and bedrock embayment classification of Roy et al. (1980). Finally the mangrove areas were delineated in the output image based on geomorphic settings. The field survey was carried out to identify mangrove species, distribution pattern, and its associated features in the appropriate locations of each setting and it was validated using GPS coordinates.

\section{Result}

The geomorphology of the mangrove forest depends on the topographic and bathymetric settings of this island, which results in the existence of all the five major geomorphic settings of mangrove. The topography of the South Andaman Island is a hilly terrain land with coastal tracts of low lying lands and elevation varies between 0 and $460 \mathrm{~m}$. The bathymetry is much more irregular and the outer margin of the shelf is frequented by several spurs and re-entrance. These favourable conditions facilitate suitable substratum for mangrove growth 
River Dominated Allochthonous

DTM Model
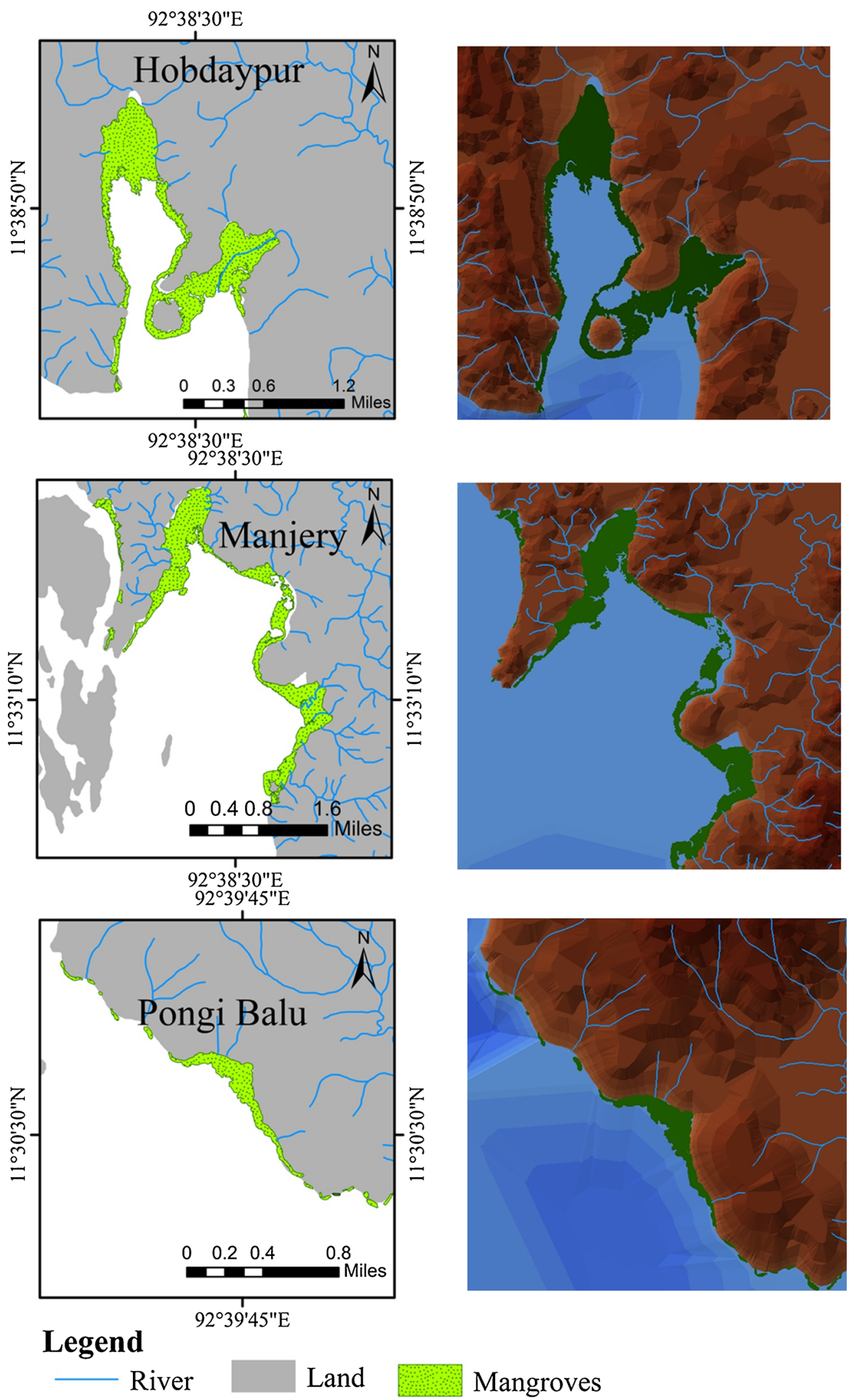

\section{Legend}

Figure 2. Finger-like protrusions of mangrove in river dominated allochthonous setting in Hobdaypur, Manjery, and Pongibalu. The DTM shows topography and bathymetry respectively. 
and form gregarious distribution of mangroves in this island.

\subsection{River dominated allochthonous}

The abundant streams and brook inlets of Hobdaypur, Manjery, and Pongibalu are the result of deposition of terrigenous sediments in the coastal margin (figure 2). These flat offshore deposits adjacent to distributaries form mangrove vegetation in the shallow bays. Due to the topographic nature, most of the streams are seasonal and few are perennial. The active river channel deposits lead to abundant distribution of mangroves and in the seasonal outlets they lead to finger-like protrusions.
The satellite image clearly shows these geomorphic structures of the mangrove forest (e.g., figure 3a). The sediment deposits are observed as silt during the rainy season with heavy terrigenous deposits and are sandy in the surface layer during the summer. The dominant mangrove species in this area was Rhizopora mucronata in the fresh water inlets and Avicennia marina was observed in the landward areas.

\subsubsection{Tide dominated allochthonous}

In south Andaman, these settings occur in the low lying flat lands surrounded by semi-enclosed seas with shallow depth and very gentle slope (a)
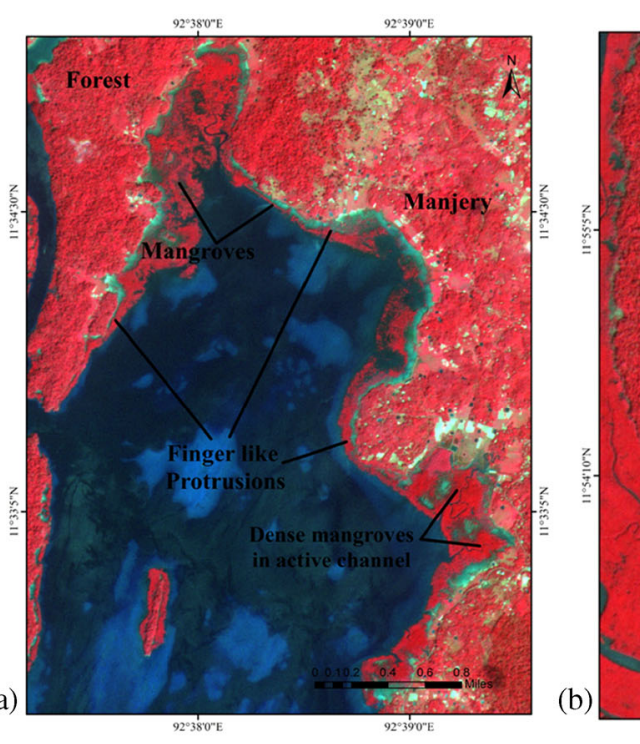

$92^{2} 4330^{\circ} \mathrm{E}$<smiles>[C+]1CCC1</smiles>

$92^{\circ} 44^{4} 15^{n} \mathrm{E}$
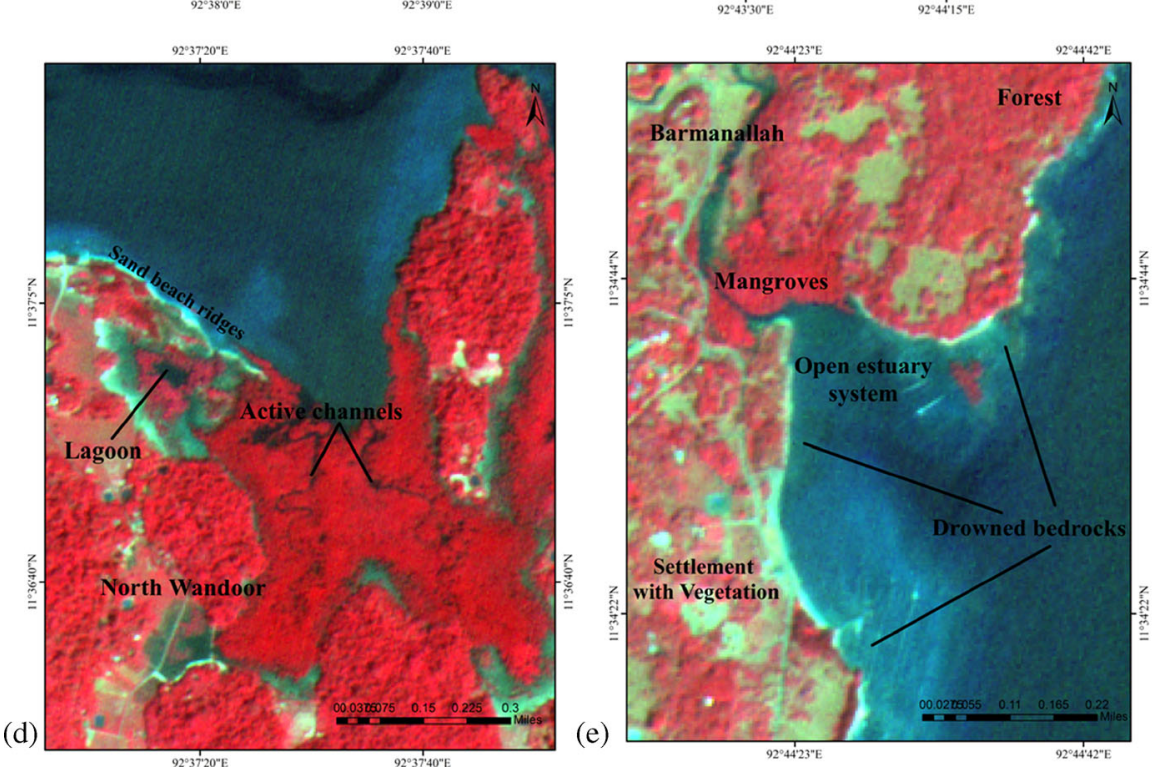

(e)

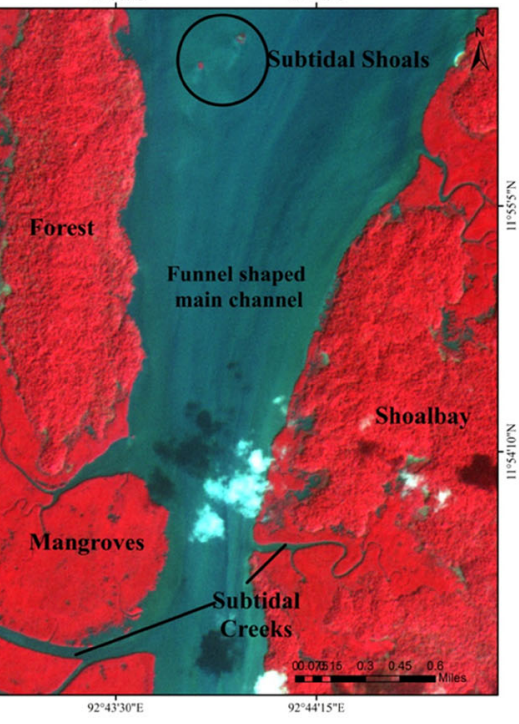

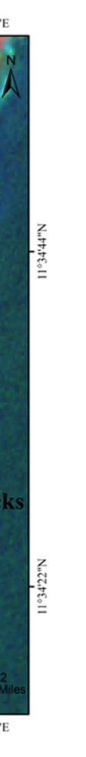

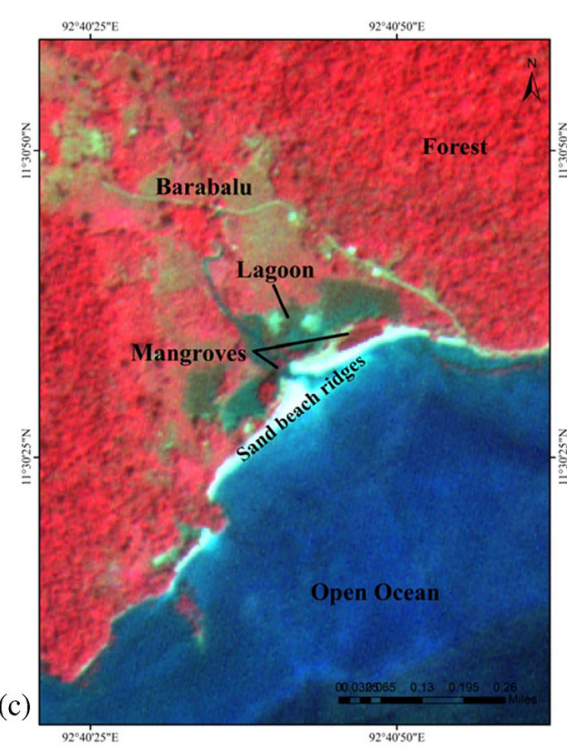

$92^{\circ} 40^{\circ} 22^{\prime \prime} \mathrm{E}$

$92^{2} 40^{\prime} 50^{\circ} \mathrm{E}$

Figure 3. FCC of the LISS IV satellite image shows the geomorphic structure of each setting. (a) Finger-like protrusions in seasonal streams and dense mangroves in the main river channel of Manjery; (b) subtidal shoals observed in the funnel shaped main creek of Shoalbay; (c) sand beach ridges and barrier lagoon observed in Barabalu which faces wave dominated open ocean; (d) adjacent lagoon near the active river channel in North Wandoor were clearly notified, even the tonal variation of mangrove communities were also visible; and (e) open estuarine mangroves observed in the river head of drowned bedrocks in Burmanallah. 
continental shelf. The shallow depth interface with water particle movement at the base of wave decreases the wave speed (Trujillo and Thruman 2009). This results in a low wave energy coast that allows the formation of creeks. This type of setting occurs in Sippighat, Saithankari, and Shoalbay, where numerous tidal creeks are fed by the streams. The tidal energy is dominant with strong bidirectional tidal currents and it disperses sediments in the offshore zone and forms elongated sand bodies (Wright et al. 1973). The main river channel is funnel shaped which is fed by numerous tidal creeks with a fine distribution of mangroves (figure 4). The subtidal shoals were observed in Shoalbay which indicates shallow depth of the tide dominated creek (figure 3b). Among the distributions the riverine mangrove species of Bruguiera and Nypa are dominant in the river inlet, Rhizopora
Tide Dominated Allochthonous
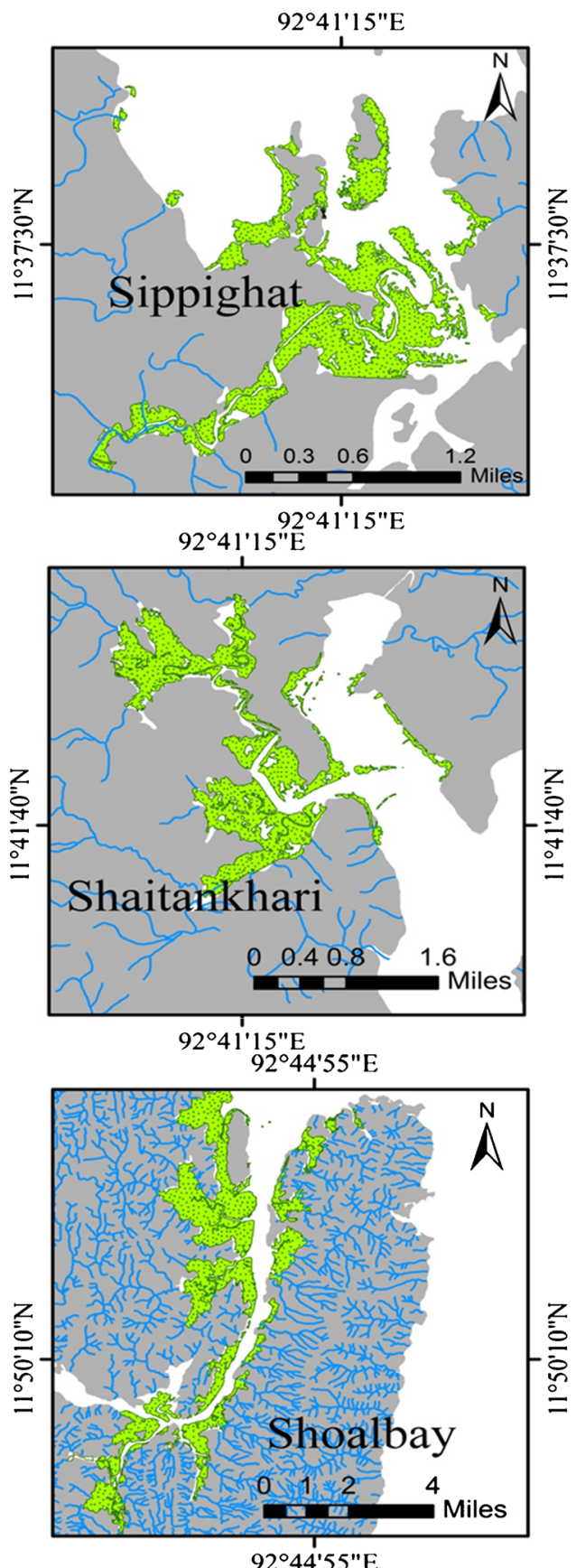

Legend
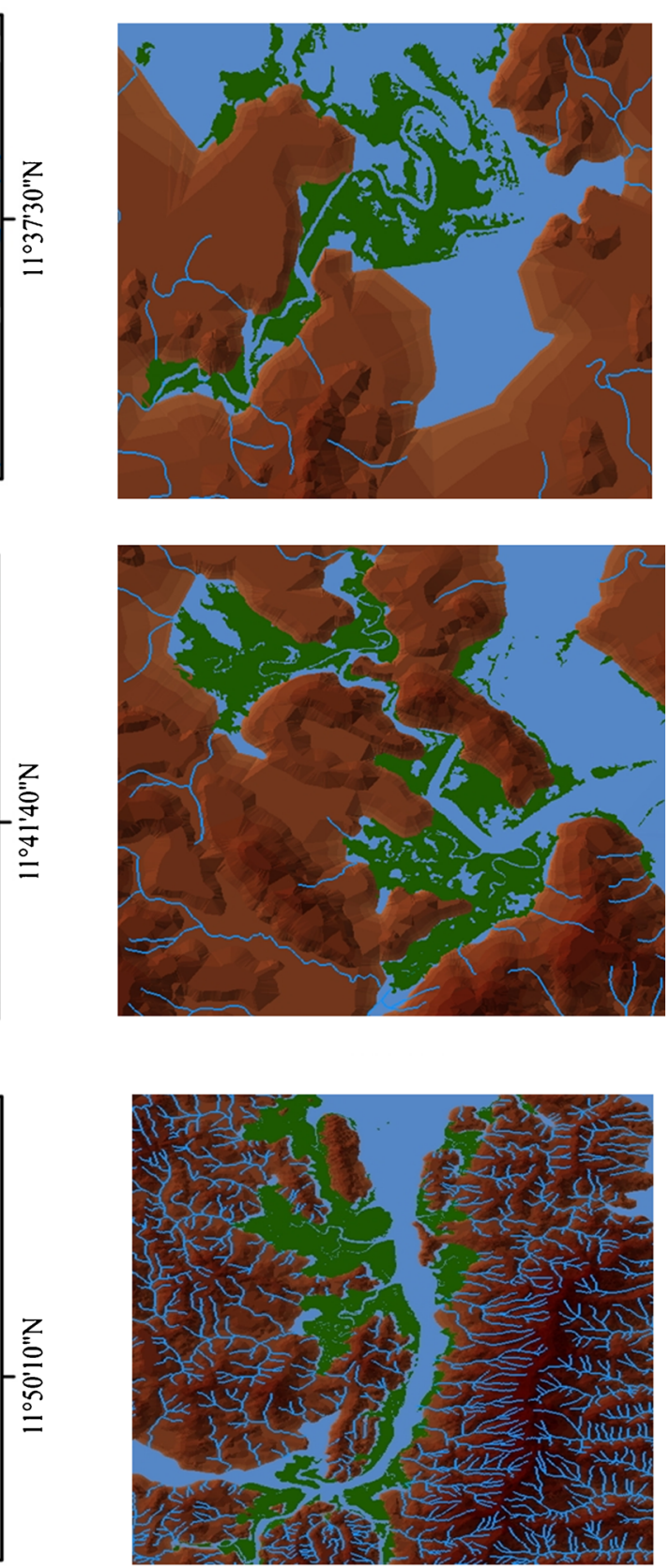

Mangroves

Figure 4. Numerous subtidal creeks with funnel shaped main creek of Sippighat, Saithankhari and Shoalbay. 
at the offshore zones, and Avicenna in the seaward end. The sediment type of this setting is clay throughout the year.

\subsubsection{Wave dominated barrier lagoon}

This type of setting mostly occurs in the bay regions and faces the open ocean (e.g., figure 3c). The continental shelf of this setting ranges from gentle to steep gradient; this leads to high wave energy coast. The bay barriers are typical for this setting and are the result of beach formation (Thom 1984) in the seaward and mangrove formation in the lagoon deposits. These features observed

\section{Wave dominated barrier lagoon}
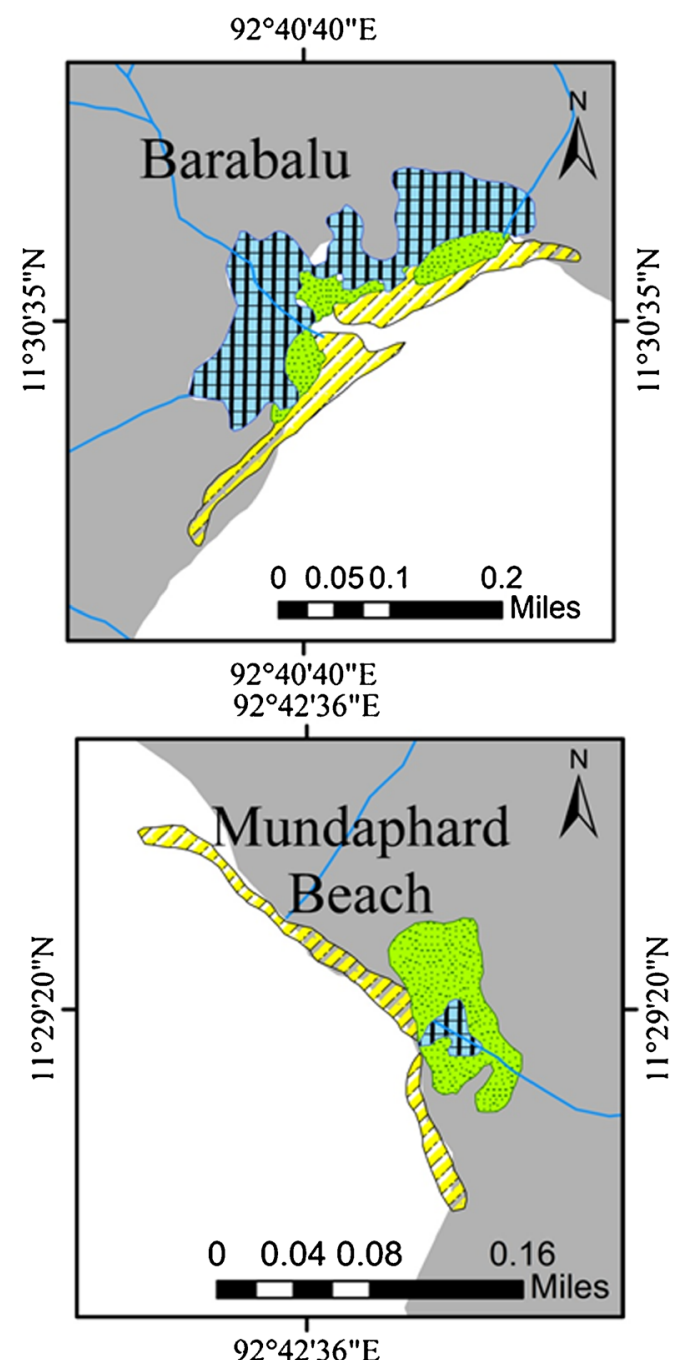

\section{Legend}

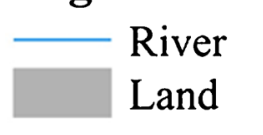

in Barabalu and Mundaphard beach in the west part of the study area which is shown in figure 5 . Salt tolerant mangroves like Avicennia marina in the barrier margin, Rhizopora species in the lagoon region are notified. The sediment type varies from the barrier to the river mouth where the sand is in the barrier, silt is in the lagoon and clay is in the river outlet.

\subsubsection{Composite-wave and river dominated}

If the coastal environment is dominated by both the wave and the river it comprises typically of beach ridges with adjacent lagoons. The deposits

\section{DTM Model}
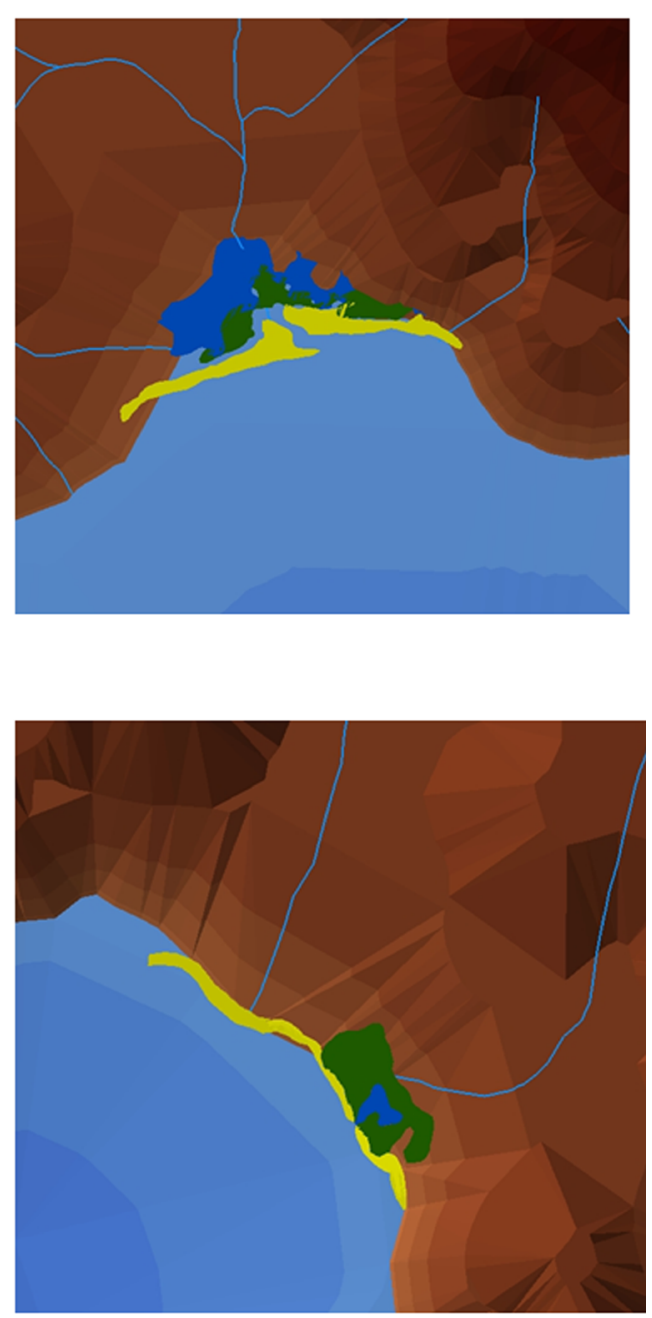

\section{Mangroves}

Figure 5. Wave dominated bay barriers observed along with lagoon in Barabalu and Mundaphard. 
debouched from the rivers are redistributed to shores by waves. It forms extensive sand sheets in the inner continental shelf, which are reworked to landward during marine transgressions and subsequent sea-level 'stillstands' (Thom 1984). This results in sand beach ridges and narrow discontinuous lagoon landwards in the adjacent tributary to the main river channel. These features were noticed at North Wandoor and Chidyatapu where the topography and the continental shelf are steep. The salt tolerant species like $A$. marina is common in lagoons and $R$. apiculata, $R$. mucronata, and Bruguiera species are common in the main river channel (figure 6). Species variation was clearly noticed in North Wandoor; even the tonal variation of species was clearly noticed in FCC of LISS satellite image, which is shown in figure (3d).

\subsection{Drowned Bed Rock Valley}

This is present in the open estuarine system behind the bed rocks in the east coast of the South Andaman Island and here the continental shelf is narrow and steep. These bed rocks are submerged during high tide and partially emerge during low tide. Patches of mangroves were observed in the

\section{Composite - wave and River Dominated}

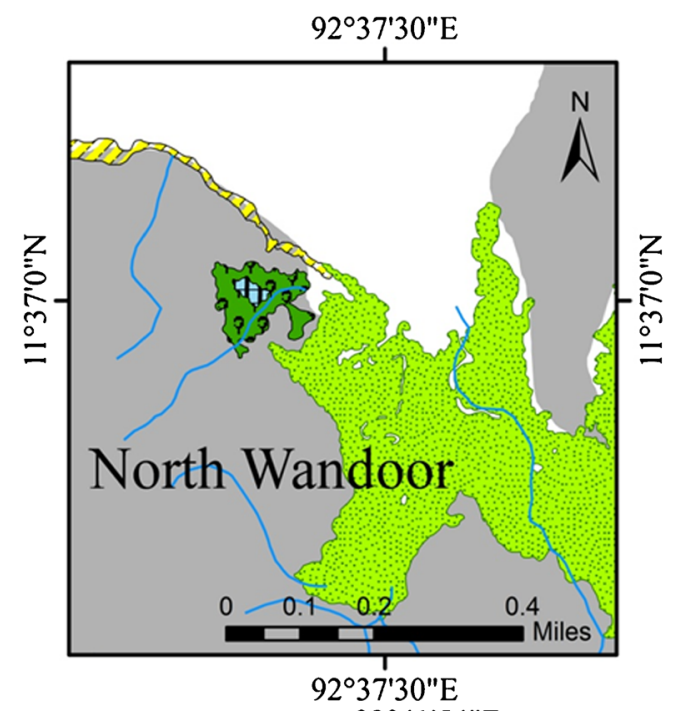

$92^{\circ} 41^{\prime} 54^{\prime \prime} \mathrm{E}$

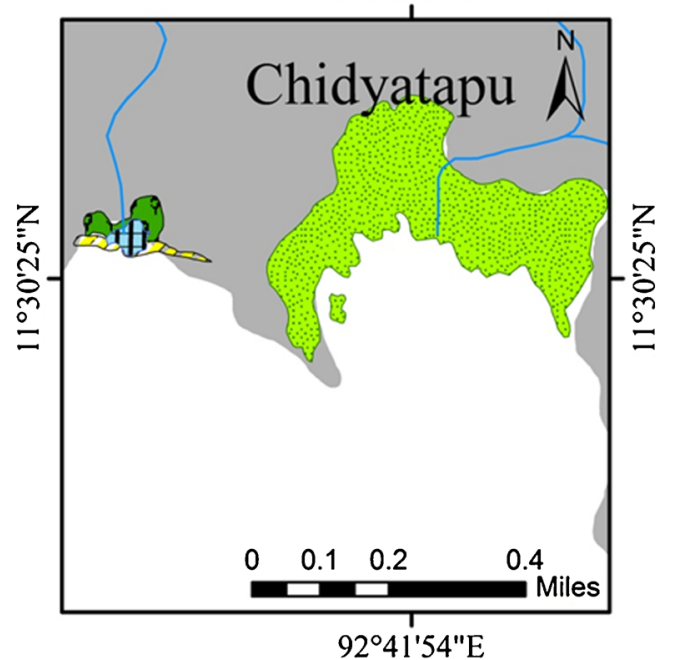

Legend

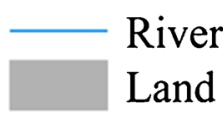

Rhizopora spp. Avicennia spp.
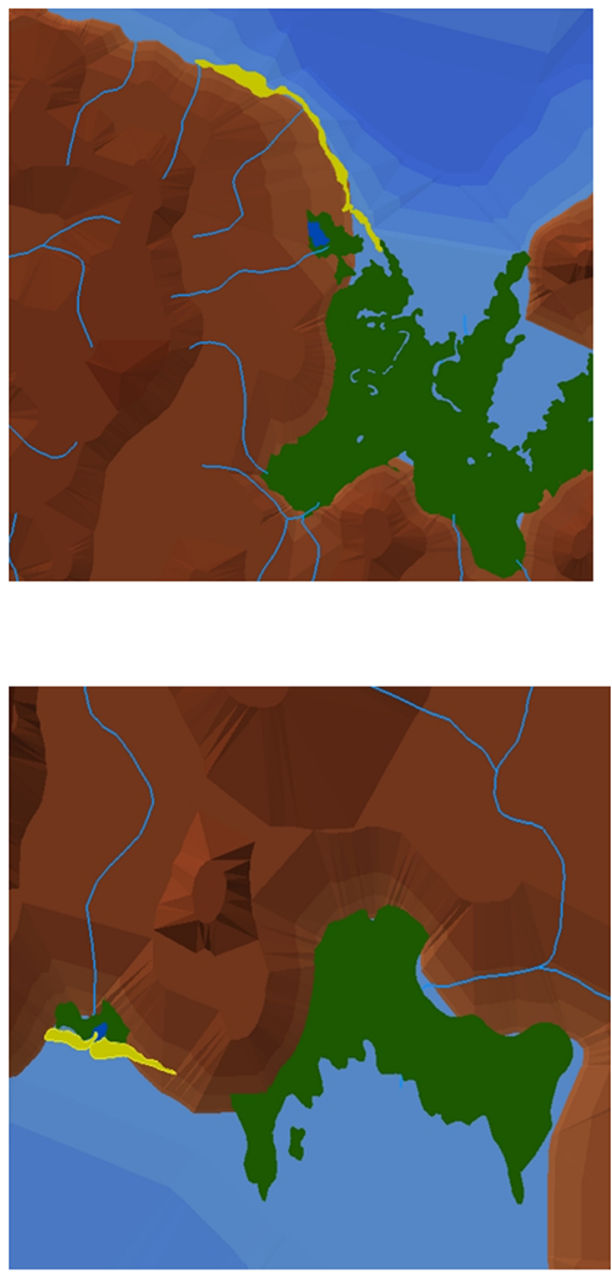

\section{姍冊 Lagoon} Sandy Beach

Figure 6. Dense mangroves in main river channel and lagoon with mangrove patch was observed in the adjacent tributary. 
Drowned Bedrock Valley

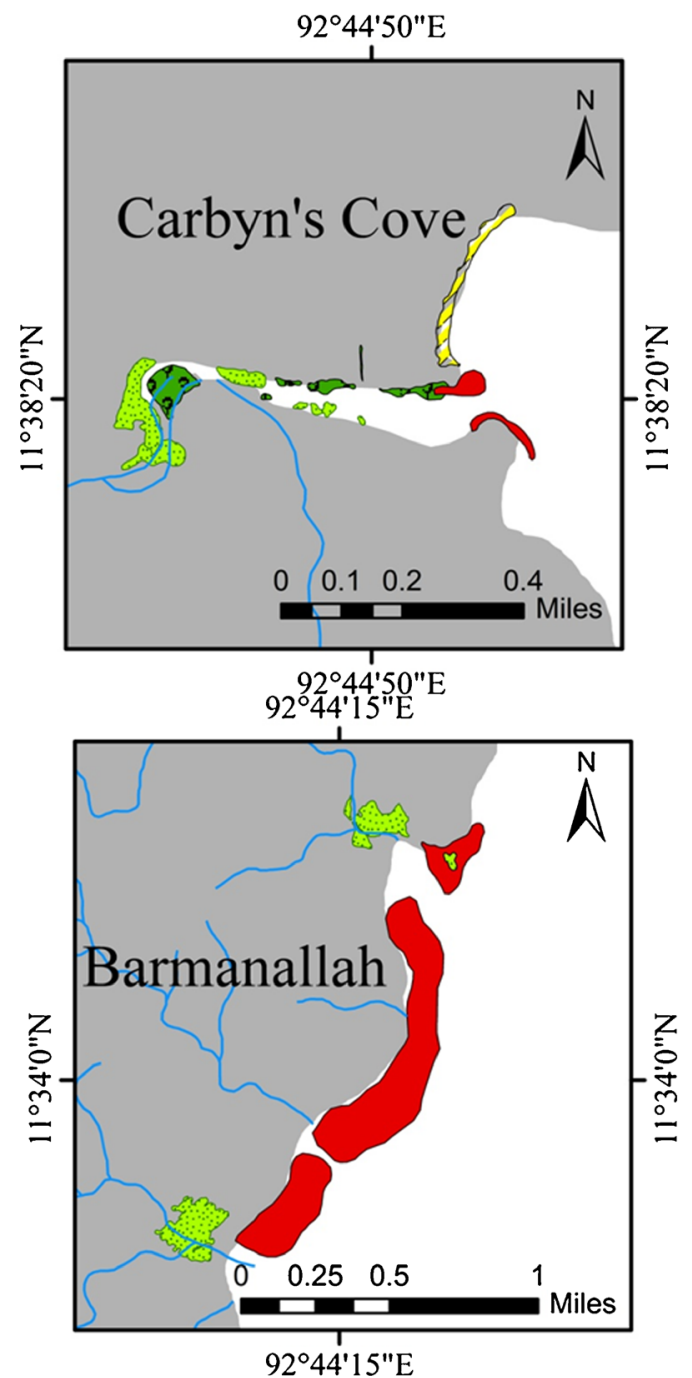

DTM Model
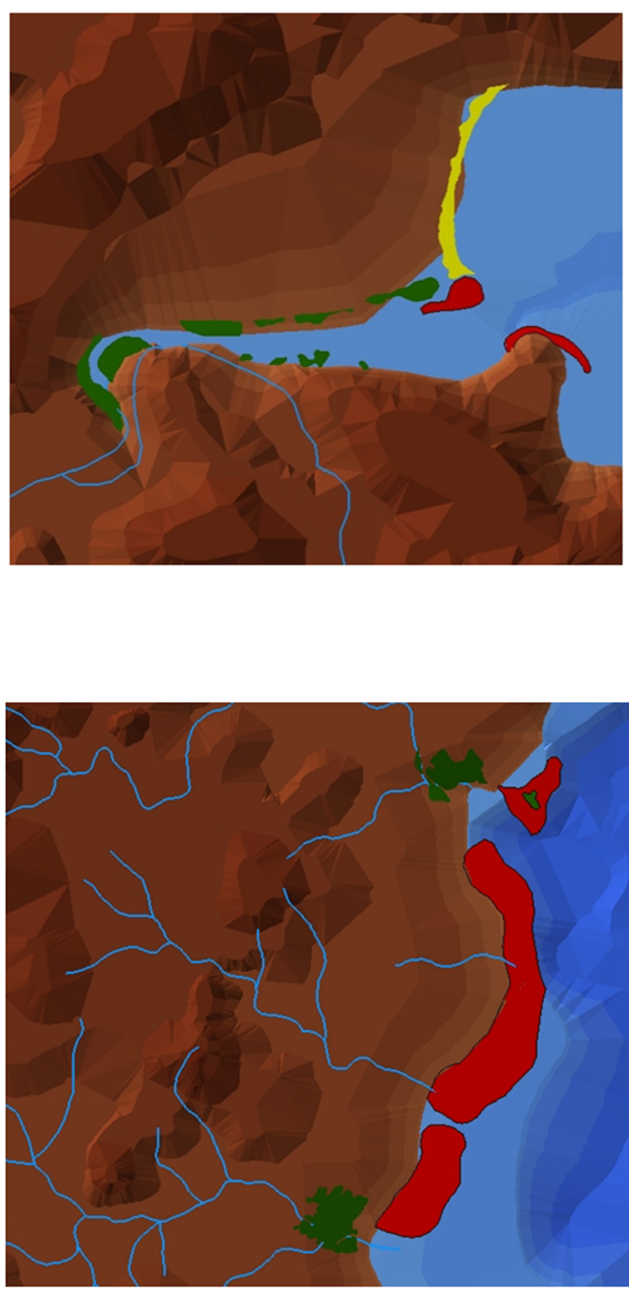

\section{Legend}
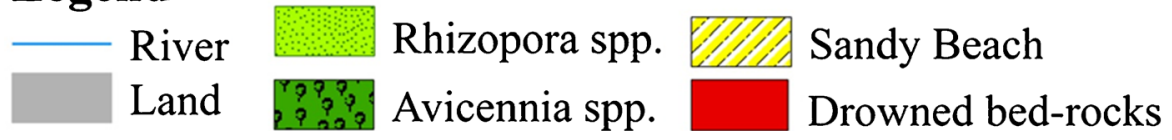

Figure 7. Drowned bedrocks with open estuarine system with mangroves on the river head was observed in Carbyn's cove and Barmanallah.

river head of this setting (figure 3e). These types were observed in Barmanallah and Carbyn's Cove, which is an open estuarine system with mangroves on river head (figure 7). The open estuarine system results in an irregular arrangement of mangrove forest as per elevation, tidal inundation periods, and freshwater flow.

\section{Discussion}

The distribution patterns of mangrove vary from each geomorphic setting, which indicates the geomorphic dependence of mangrove ecosystem. The highly undulated terrain of the South Andaman
Island (Dam and Grinson 2010) results in maximum seasonal streams and a few perennial streams and there is no major river in this island. According to DEM results, the eastern side is narrow extending up to $10 \mathrm{~m}$ with an average slope of 2.5 degrees and undulating craggy terrain with a number of long ridges and troughs. Whereas the western side is smooth and flat, and it extends up to $1000 \mathrm{~m}$ with the slope less than 1 degree (Malik 2008). Most of the streams flow towards the western part of the island and this leads to finger-like protrusions of mangroves in Pongibalu, Manjery, and Hobdaypur. From the topographic point of view, the land locked semi-enclosed seas with very gentle elevation were observed in Sippighat, Saithankhari, 
and Shoalbay. This facilitates frequent tidal inundation over a large area and forms the habitat for the wide diversity of mangroves. The consistency of mangrove substratum varies from semi-fluid mud to hard substratum depending upon the period of tidal inundation (Das and Dev 1989).

Coastal flats of this island are admixture of sand, silt clay, and alluvium material, together with fine fragments of coral deposits (Tikader and Das 1985). In wave dominated coast, the discharges from the streams are reworked by the high wave energy which leads to formation of bay barriers (Swift 1976), such that Barabalu and Mundaphard beach silt and sand deposits dominate the hard muddy substratum of mangroves and beach formation near it. The high river discharge and wave action results in the formation of beach ridges and narrow discontinuous lagoons adjacent to the main river channel in North Wandoor and Chidyatapu. High saline environment in the lagoons lead to the existence of salt tolerant mangroves and high river discharge results in the existence of riverine mangroves in the main river channel. The tidal creeks in drowned bedrock valleys consist of muddy soils which are frequently inundated by tidal waves and reworked by the wave action (Roy et al. 1980). In mangrove patches in the river heads of Carbyn's cove and Barmanallah, the wave action and fresh water discharge determine the forest extent and species distribution. The insufficient fresh water flow leads to the existence of few sparse patches of salt tolerant mangroves in Carbyn's cove and enormous river flow and wide sheet rocks lead to low wave action and fine deposition which results in dense patches of mangroves in the estuarine heads of Barmanallah.

Apart from these settings, mangroves also exist in the low energy coasts of carbonate platform deposits of this island (Selvam 2003), which is mostly behind the reef barriers. But only clumps and scattered patches exist in this type of carbonate platform and salt tolerant species of Avicennia and Sonneratia are commonly observed in these deposits.

\subsection{Basic understanding from this study}

Mangroves of this island were drastically affected by December 2004 tsunami particularly in the areas of Sippighat, Saithankhari, and Shoalbay, where severe damage and degradation was observed (Dharanirajan et al. 2007; Dam Roy and Krishnan 2005). The geomorphic settings of these areas show the tide dominated coast with gentle elevation. The land subsidence caused inundation which results in rise in the seawater level up to $1 \mathrm{~m}$ (Subramanian et al. 2005); even a small rise in the sea level inundation destroys survivability of mangroves (Cheeseman 1994). This leads to damage and degradation of mangrove communities and also habitat alteration of mangrove seedlings observed in the field visit. Hence the geomorphic study of mangrove ecosystem provides the basic scenario to understand the fragile ecosystem.

\section{Conclusion}

The term fragile ecosystem for mangroves indicates the unreliable conditions that are mainly influenced by the geomorphology of the coast. Geospatial techniques were used to study the micro-topography of the mangrove ecosystem from the topographic and bathymetric contours, which were digitized onscreen using ARCGIS 10 software. Mangrove forests and other coastal land cover features were identified and mapped in the LISS IV satellite image, using visual interpretation technique. The DEM and DTM models were generated to show the elevation and the terrain models,

Table 1. Classification of mangrove geomorphic setting in South Andaman Island.

\begin{tabular}{|c|c|c|c|c|}
\hline Sl. no & Geomorphic setting & Location in study area & Dominant feature & Resulted structure \\
\hline 1 & $\begin{array}{l}\text { River dominated } \\
\text { allochtnonous }\end{array}$ & $\begin{array}{l}\text { Hobdaypur, Manjery and } \\
\text { Pongibalu }\end{array}$ & $\begin{array}{l}\text { Rivers (seasonal } \\
\text { and perennial) }\end{array}$ & $\begin{array}{l}\text { Abandoned distributaries and } \\
\text { finger-like mangrove protrusions. }\end{array}$ \\
\hline 2 & $\begin{array}{l}\text { Tide dominated } \\
\text { allochthonous }\end{array}$ & $\begin{array}{l}\text { Sippighat, Saithankhari } \\
\text { and Shoalbay }\end{array}$ & High tidal influence & $\begin{array}{l}\text { Numerous tidal creeks with funnel- } \\
\text { shaped main river channel and } \\
\text { subtidal shoals on river mouth. }\end{array}$ \\
\hline 3 & $\begin{array}{l}\text { Wave dominated } \\
\text { barrier lagoon }\end{array}$ & $\begin{array}{l}\text { Barabalu and } \\
\text { Chidyatapu }\end{array}$ & High wave energy & $\begin{array}{l}\text { Sand barrier with beach ridges } \\
\text { and lagoons in the river mouth. }\end{array}$ \\
\hline 4 & $\begin{array}{l}\text { Composite-wave and } \\
\text { river dominated }\end{array}$ & $\begin{array}{l}\text { North Wandoor and } \\
\text { Mundaphard Beach }\end{array}$ & $\begin{array}{l}\text { High wave energy and } \\
\text { river disharge }\end{array}$ & $\begin{array}{l}\text { Adjacent lagoons near main river } \\
\text { channel, sand beach ridges and salt } \\
\text { tolerant species in adjacent lagoon. }\end{array}$ \\
\hline 5 & $\begin{array}{l}\text { Drowned Bed Rock } \\
\text { valley }\end{array}$ & $\begin{array}{l}\text { Carbyn's Cove and } \\
\text { Burmanala }\end{array}$ & $\begin{array}{l}\text { Wave energy in coast and } \\
\text { moderate tidal variation }\end{array}$ & $\begin{array}{l}\text { Open estuarine system, drowned } \\
\text { bedrocks in coast and mangroves } \\
\text { in river head. }\end{array}$ \\
\hline
\end{tabular}


respectively that are used to understand geomorphic structures, their influence on the mangrove forests and the surrounding habitat. The coast may be dominated by either river, wave, or tide, due to the geomorphology of the location. The variations are interpreted with major mangrove settings such as river-dominated allochthonous, tide-dominated allochthonous, wave-dominated barrier lagoon, composite-wave and river dominated, and Drowned Bed Rock valley. Finally, from the result it is identified that all the five types of geomorphic settings exist in the South Andaman Island (table 1). This study is used to classify the mangrove forest based on the geomorphic setting, which is an important factor that influences the distribution, species diversity and forest structure of the mangrove forest. The wide damages and changes in the mangrove forest after the December 2004 tsunami was observed more in the tide dominated allochthonous due to the geomorphic setting of this type. Since, understanding the geomorphology of mangroves in the local scale is useful for the various management methods of this ecosystem, this study recommends the decision makers to pay more attention towards monitoring the mangrove forests according to the geomorphic settings that are used to delineate management strategies for the various mangrove settings of this island.

\section{Acknowledgements}

Authors express sincere thanks to DFFO and Mr. Dinesh Kannan, Divisional Forest Officer, Andaman Forest Department, for their immense help and technical guidelines in the field survey and for their moral support. Special thanks to Pondicherry University, Puducherry for funding the research.

\section{References}

Alongi D M 2008 Mangrove forests: Resilience, protection from tsunamis, and responses to global climate change; Estuarine Coast. Shelf Sci. 76 1-13.

Chakravarty N V K, Tripathi K P and Gangwar B 1987 Acomparative study of coastal climate with special reference to Andamans, India. I. Temperature and rainfall; J. Andaman Sci. Assoc. 3(2) 119-124.

Cheeseman J M 1994 Depressions of photosynthesis in mangrove canopies; In: Photo inhibition of photosynthesis: From molecular mechanisms to the field (eds) Baker N R and Bowyer J R, BIOS, Oxford, pp. 377-389.

Dam Roy S and Grisnon G 2010 Marine resources of islands: Status and approaches for sustainable exploitation/conservation with special emphasis to Andaman and Nicobar; Ind. J. Animal Sci. 80(4) 57-62.

Dam Roy S and Krishnan P 2005 Mangrove stands of Andamans vis-à-vis tsunami; Curr. Sci. 89(11) 10801084 .
Das A K and Dev Roy M K 1989 A general account of the mangrove fauna of Andaman and Nicobar Islands, Fauna of conservation areas; Zoological Survey of India, Calcutta.

Dharanirajan K, Pandian P K, Gurugnanam B, Narayanan R M and Ramachandran S 2007 An integrated study for the assessment of tsunami impacts: A case study of South Andaman Island, India using remote sensing and GIS; Coastal Eng. J. 49(3) 229-266.

Duke N C 1992 Mangrove Floristics and Biogeography; In: Tropical Mangrove Ecosystems (eds) Robertson A I and Alongi D M, Coastal and Estuarine Geophysical Union, Washington DC, USA.

Farnsworth E J and Ellison A M 1997 The global conservation status of mangroves; Ambio 26 328-334.

Gilman E L, Ellison J, Duke N C and Field C 2008 Threats to mangroves from climate change and adaptation options: A review; Aquatic Botany 89 237-250.

Gnanappazham L and Selvam V 2011 The dynamics in the distribution of mangrove forests in Pichavaram, South India - perception by user community and remote sensing; Geocarto International 26(6) 475-490.

Gokarn S G, Gupta G, Dutta S and Hazarika N 2006 Geoelectric structure in the Andaman Islands using magnetotelluric studies; Earth Planet Space 58 259-264.

IIRS (Indian Institute of Remote Sensing) 2003 Biodiversity characterisation at landscape level in Andaman and Nicobar Islands using Satellite Remote Sensing and Geographic Information Systems; Department of Space, Government of India, Dehradun.

Kathiresan K and Rajendran N 2005 Coastal mangrove forests mitigated tsunami; Estuarine Coast. Shelf Sci. $\mathbf{6 5}$ 601-606.

Kuenzer C, Bluemel A, Quoc TV and Dech S 2011 Remote sensing of mangrove ecosystems: A review; Remote Sens. 3 878-928.

Malik T K 2008 Marine geology: A scenario around Indian coasts; New Academic Publishers, India.

Manson F J, Loneragan N R, Skilleter G A and Phinn S R 2005 An evaluation of the evidence for linkages between mangroves and fisheries; In: A synthesis of the literature and identification of research directions. Oceanography and marine biology: An annual review (eds) Gibson R N, Atkinson R J A and Gordon J D M, Taylor and Francis, London, UK, 43 485-515.

Mumby P J, Edwards A J, Arias-Gonzáles E, Lindeman K C, Blackwell P G, Gall A, Gorczynska M I, Harborne A R, Pescod C L, Renken H, Wabnitz C C and Llewellyn G 2004 Mangrove enhance the biomass of coral reef fish communities in the Caribbean; Nature 427 533-536.

Oliver J 1982 The geographic and environmental aspects of mangrove communities: Climate; In: Mangrove ecosystems in Australia: Structure, function and management (ed.) B F Clough, Australian National University Press, Canberra, pp. 2-30.

Othman M A 1994 Value of mangroves in coastal protection; Hydrobiologia 285 277-282.

Rajagopalan M S 1987 Mangroves as Component of Coastal Ecosystems of the Andamans; Proceedings of the Symposium on Management of Coastal Ecosystems and Oceanic Resources of the Andamans, Central Agricultural Research Institute, Port Blair.

Ramachandran S, Anitha S, Balamurugan V, Dharanirajan K, Ezhil Vendhan K, Divien MIP, Senthil Vel A, Sujjahad Hussain I and Udayaraj A 2005 Ecological impact of tsunami on Nicobar Islands (Camorta, Katchal, Nancowry and Trinkat); Curr. Sci. 89(1) 195-200.

Robert R T and Victor H R-M 2005 Developing performance measures of mangrove wetlands using simulation models 
of hydrology, nutrient biogeochemistry, and community dynamics; J. Coast. Res. 40 79-93.

Roy P S, Thom B G and Wright L D 1980 Holocene sequences on an embayed high-energy coast: An evolutionary model; Sedim. Geol. 26 1-19.

SAC (Space Application Centre) 1991 Manual for mapping of coastal wetlands/landforms and shoreline changes using satellite data; Space Application Centre (ISRO), Ahmedabad, India.

SAC (Space Application Centre) 2011 Coastal Zones of India; Space Application Centre (ISRO), Ahmedabad, India.

Selvam V 2003 Environmental classification of mangrove wetlands of India; Curr. Sci. 84(6) 757-765.

Sharma V and Srinivasan M S 2007 Geology of AndamanNicobar: The Neogene; Capital Publishing Company, New Delhi.

Subramanian A N 2004 Marine Environment: Biodiversity in Mangrove Ecosystems; In: UNU-INWEH-UNESCO International training course on mangroves and biodiversity, Tamil Nadu, India (eds) Balasubramanian T, Kathiresan $\mathrm{K}$ and Ajmal Khan S, pp. 18-25.

Subramanian B R, Ramanamurthy M V, Sundaramoorthy S, Pari Y, Ranga Rao V, Mishra P, Bhat M, Usha T and Venkatesan R 2005 Inundation of sea water in Andaman and Nicobar Islands and parts of Tamil Nadu coast during 2004 Sumatra tsunami; Curr. Sci. 88(11) 1736-1740.

Stoddart D R 1980 Mangroves as successional stages, inner reefs of the northern Great Barrier Reef; J. Biogeogr. 7 269-284.

Swift D J P 1976 Continental shelf sedimentation; In: Marine Sediment Transport and Environmental Management (eds) Stanley D J and Swift D J P, John Wiley, pp. 311-350.

Thom B G 1984 Coastal landforms and geomorphic processes; In: The mangrove ecosystem: Research methods (eds) Samuel C Snedaker and Jane G Snedaker, UNESCO, United Kingdom, pp. 3-17.

Thom B G and Wright L D 1982 Geomorphology of the Purari Delta. Purari River (Wabo) hydroelectric scheme; Environ. Stud. 17 1-24.

Thom B G, Wright L D and Coleman J M 1975 Mangrove ecology and deltaic estuarine geomorphology: Cambridge Gulf-Ord River, western Australia; J. Ecol. 63 203232.

Tikader B K and Das A K 1985 Glimpses of animal life of Andaman and Nicobar Islands, ZSI, India.

Tomlinson P B 1986 The botany of mangroves; Cambridge University Press, Cambridge.

Trujillo P A and Thurman V H 2009 Essentials of Oceanography, 10th edn, Prentice Hall Publication, United States.

Woodroffe C D, Stoddart D R and Giglioli M EC 1980 Pleistocene patch reefs and holocene swamp morphology, Grand Cayman Island, West Indies; J. Biogeogr. 7 103-113.

Wright L D, Coleman J M and Erickson M W 1974 Analysis of major river systems and their deltas: Morphologic and process comparisons; Baton Rouge, Coastal Studies Institute Louisiana State University Press (Tech. Report No. 156).

Wright L D, Coleman J M and Thom B G 1973 Processes of channel development in a high-tide-range environment: Cambridge Gulf-Ord River Delta; J. Geol. 81 15-41. 